\title{
小型コンクリートユニットを用 COMPRESSIVE BEHAVIOR OF いたRM組積体の圧縮性状 FULLY GROUTED CONCRETE MASONRY USING SMALL-SIZE CONCRETE UNITS
}

\author{
稲井栄一—— 1 \\ 山本大介— $* 3$ \\ 高橋和雄 —— $* 2$ \\ 石井克侑—— $* 4$ \\ キーワード : \\ 小型コンクリートユニット，鉄筋コンクリート組積造，プリズム試験体，圧 \\ 縮性状 \\ Keywords : \\ Small-size concrete unit, Reinforced concrete masonry, Fully grouted prism, \\ Compressive behavior
}

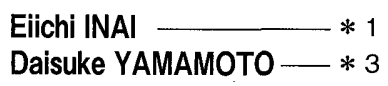

Kazuo TAKAHASHI $-* 2$
Katsuyuki ISHII- $-* 4$

The authors have been developing low-rise reinforced concrete masonry buildings with the wall thickness of $150 \mathrm{~mm}$, for the purpose of the increase of inner space of buildings, the decrease of building weight, and the usage of the standard building module of $300 \mathrm{~mm}$. In order to realize the buildings, compressive behaviors of fully grouted concrete masonry prisms, using newly developed small-size units with the strength of $40 \mathrm{~N} / \mathrm{mm}^{2}$ class and grout concrete of the strength of $40-60 \mathrm{~N} / \mathrm{mm}^{2}$, were investigated. Special pre-mixed cement mortal was used for the joints to obtain high out-of-plane bending performance.

\section{1.はじめに}

鉄筋コンクリート組積造（以下、RM造と呼ぶ）建築物は、従来、 壁厚 $200 \mathrm{~mm}$ を基本とした、いわゆる 12 型、23 型のユニットを用い て構築されている。著者等は、都市部の狭小敷地等を考慮し、低層 用 RM造建築物を対象に、(1)居住スペースの増加、(2)躯体重量の低 減、(3)標淮的モデュール $(300 \mathrm{~mm})$ の採用を目的として、壁厚を $150 \mathrm{~mm}$ とする RM構工法の開発を行っている。本 RM構工法の特徴を以下 に記す。

1) 使用するユニットは、施工の合理化も考慮し小型軽量のものとし、 ユニットモデュール寸法が厚さ $150 \mathrm{~mm}$ 、高さ $150 \mathrm{~mm}$ 、長さ $300 \mathrm{~mm}$ で、形状が H形のものを採用した。縦目地は打込み目地、横目地 は目地厚を $1 \mathrm{~mm}$ と寸る極薄目地のハイブリッド型としている(図 1 参照)。また、実施工時には、ユニット形状の特徴を活かし先組 み鉄筋（格子鉄筋）構法を採用することも想定している（図 2 参 照)。

2) ユニットの圧縮強度は、文献 ${ }^{1)}$ の 3 階建て R M 造建築物の試設計 の結果をもとに、 $40 \mathrm{~N} / \mathrm{mm}^{2}$ クラスとし、 $\mathrm{RM}$ 造組積体の設計基準強 度としては $27 \sim 33 \mathrm{~N} / \mathrm{mm}^{2}$ 想定している。

3） R M 造建築物の耐力壁には、スラブより長期荷重として面外モー メントが作用するため、壁厚が薄い場合には目地部や接合部に曲 げひび割れが生じる可能性がある。そこで、目地材として、接着 性能を高めるためにポリマーディスパージョンを混入した特殊既 調合セメントモルタルを開発し用いることにしている。

本論では、新しく開発したモデュール寸法が厚さ $150 \mathrm{~mm}$ 、高さ $150 \mathrm{~mm}$ 、長さ $300 \mathrm{~mm}$ のコンクリートユニットの材料特性、ならびに、
このユニットに 40〜 60N/ $\mathrm{mm}^{2}$ クラスのグラウトを充填したプリズム 試験体の圧縮性状について報告寸る。なお、本論の一部は、文献 ${ }^{2)}$ に報告している。また、特殊既調合セメントモルタルの接着性能に 関しては、RM組積体の面外曲げ実験も実施しており、良好な性能 が得られることを確認している ${ }^{3)}$ 。この面外曲げ実験に関しては別 途報告する予定である。

\section{2.プリズム試験体}

表 1 にプリズム試験体（横目地 2 箇所のユニット 3 段積み）の一 覧を示す。また、表 2 に試験体に使用した材料の一覧を示す。プリ ズム試験体は 5 種類で、使用するユニットは各試験体共通とし、同 一の材料、配合、製造日のものを使用している。目地材はポリマー ディスパージョンを混入した特殊既調合セメントモルタルを基本と し、比較用の試験体に、打込み目地 RM造用の予備接着剤である変 成シリコーン系接着剤を用いた。ユニット製造後 4 週に目地材を用 いて組積を行った。グラウトは、材齢 4 週の想定強度（以下 $F_{g}$ と記

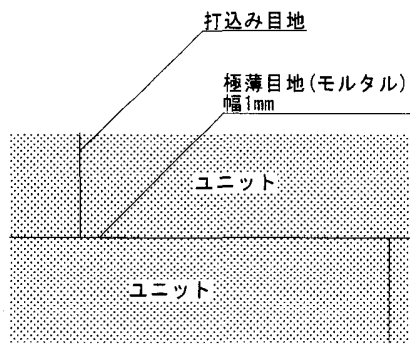

図 1 ハイブリッド型目地構法

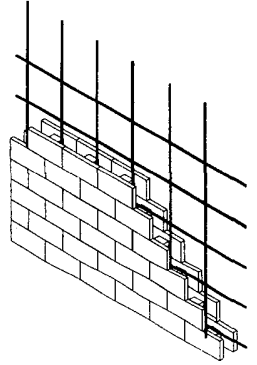

図 2 先組み鉄筋構法

\footnotetext{
*1 山口大学大学院理工学研究科 准教授. 工博

（干755-8611 山口県宇部市常盤台 2丁目16-1)

*2 太陽セメント工業(侏) 技術開発室・室長

*3 山口大学大学院理工学研究科博士前期課程 大学院生

*4 太陽セメント工業(株) 社長・工博
}

*1 Assoc. Prof., Graduate School of Science and Engineering, Yamaguchi Univ., Dr. Eng.

* 2 Manager, Technology \& Development Div., Taiyo Cement Industrial Corp.

* 3 Graduate Student, Graduate School of Science and Eng., Yamaguchi Univ.

*4 President, Taiyo Cement Industrial Corp., Dr. Eng. 
表 1 プリズム試験体一覧

\begin{tabular}{|c|c|c|c|c|c|}
\hline 試験体 & $\begin{array}{c}\text { 寸洼(mm) } \\
\text { 厘さ×高さ×龙さ }\end{array}$ & \begin{tabular}{|c|} 
zニット(num) \\
厚さ×高さ $\times$ 長さ \\
\end{tabular} & グラウト & 目地 & 加力日 \\
\hline $\mathrm{P} 40 \mathrm{CP}$ & \multirow{5}{*}{$150 \times 149 \times 229$} & \multirow{5}{*}{$150 \times 149 \times 299$} & $\begin{array}{c}\text { コンクリート } \\
\mathrm{F}_{\mathrm{g}} 40 \\
\end{array}$ & \multirow{4}{*}{$\begin{array}{l}\text { 特殊既調合 } \\
\text { セメントモルタル }\end{array}$} & \multirow{5}{*}{$\mid \begin{array}{c}\text { グラウト材蒾的 } \\
4 \text { 週 } \\
13 \text { 週 } \\
26 \text { 週 }\end{array}$} \\
\hline P50CP & & & \begin{tabular}{|c|} 
シンクリートー \\
$\mathrm{F}_{\mathrm{g}} 50$ \\
\end{tabular} & & \\
\hline P60CP & & & \begin{tabular}{|c|} 
コンクリート \\
$\mathrm{F}_{\mathrm{g}} 60$ \\
\end{tabular} & & \\
\hline Р50MP & & & $\begin{array}{c}\text { モルタル } \\
\mathrm{F}_{\mathrm{g}} 50 \\
\end{array}$ & & \\
\hline $\mathrm{P} 50 \mathrm{CS}$ & & & 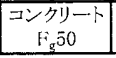 & $\begin{array}{c}\begin{array}{c}\text { 打远双目地RM造用 } \\
\text { 予備接着剂 }\end{array} \\
\end{array}$ & \\
\hline
\end{tabular}

P40CP4 -フリズム試験体

Lグラウ卜強度と材料(C: コンクリート $\mathrm{M}:$ モルタル)

—目地( $\mathrm{P}:$ 特殊プレシックスモルタル S: 打込子目地R.M造用予備接着剂)

一材齢 $(4: 4$ 週に実験 $13: 13$ 週に笑験 $26: 26$ 週に実験)

す）が 40、50、60N/ $\mathrm{mm}^{2}$ のコンクリートと $50 \mathrm{~N} / \mathrm{mm}^{2}$ のモルタルの 4 種類であり、組積後 1 週（ユニット製造後 5 週）に、全ての試験体 に同時に充填した。

試験体数は、各種類 9 体でグラウト充填後 4 週、13 週および 26 週に 3 体ずつ圧縮実験を行った。また、ユニット（1 段）に4 種類 のグラウトを充填した充填ユニットを各種類 9 体製作し、プリズム 試験体と同様、グラウト充填後 4 週、13 週、26 週に 3 体ずつ圧縮実 験を行っている。試験体の製作に用いたコニット、グラウトおよび 目地材の材料試験もプリズム試験体の加力と同一時に害施している。 これら試験体は全て気中養生とした。図 3 に本実験のユニットの製 造、試験体の製作、実験の工程を示す。

\section{3. 使用材料の特性}

\section{1 コンクリートユニット}

図 4 に使用したユニットの形状を示す。寸法は $150 \times 149 \times 299$ で 目地幅は $1 \mathrm{~mm}$ を想定している。ウェブは中央部 1 䇢所で、H形の形 状をしている。フェイスシェルの平均厚さは $29 \mathrm{~mm}$ 、容積空洞率は 55.4\%である。

表 3 にプリズム試験体の加力時に行ったュニットの材料試験結果 を示す。なお、表中の值は試験体 3 体の平均值である。表中のクー ポン試験体は、フェイスシェルから切り出した直方体 $(60 \times 60 \times$ $29 \mathrm{~mm}$ ）で、その圧縮強度とヤング係数、ポアソン比の関係を図 5 お よび図 6 に示す。クーポン試験体の圧縮強度は、組積した場合の鈶 直方向(ユニット製造時のコンクリートの打設方向) の圧縮強度が、 水平方向より若干高い強度を示した。これは、成形のためのプレス 方向と一致しており、その影響が現れたものと考えられる。ヤング 係数は既往の算定式である(1) 式 ${ }^{4)}$ と良好な対応を示している。ポア ソン比はほぼ 0.2 である。また、フェイスシェルの引張試験から、 $2.01 \mathrm{~N} / \mathrm{mm}^{2}$ の引張強度が得られている。これらのことから、試験した 範囲では、本ユニットのコンクリートは圧縮強度が $40 \sim 50 \mathrm{~N} / \mathrm{mm}^{2}$ 程 度の普通コンクリートと類似の物性を有していると考えられる。

$$
E_{C}=3.35 \times 10^{+} \times\left(\frac{\sigma_{B}}{60}\right)^{1 / 3}
$$

ここで、 $E_{C} ：$ :コンクリートのヤング係数 $\left(\mathrm{N} / \mathrm{mm}^{2}\right)$

$$
\sigma_{B}: \text { コンクリートの圧縮強度 }\left(\mathrm{N} / \mathrm{mm}^{2}\right)
$$

なお、 4 週、13 週および 26 週のプリズム試験体加力時には、ユニ ットの全形試験体の圧縮試験も行っている。試験体 3 体の圧縮強度 (フェイスシェル実断面で換算) の平均值を表 3 に示しているが、 クーポン試験体と全形試験体の圧縮強度にはややばらつきがあった。

\begin{tabular}{|c|c|}
\hline 使用材料 & 種類 \\
\hline ユニット & 小型ユニット圧縮強度 $40 \mathrm{~N} / \mathrm{mm}^{2}$ 以上 \\
\hline 目地材 & $\begin{array}{l}\text { 特殊既調合セメントモルタル } \\
\text { 打ち込み目地RM造用予備接着剤 }\end{array}$ \\
\hline \multirow{2}{*}{ グラウト材 } & \begin{tabular}{c|l} 
コンクリート & $\begin{array}{l}\text { 材跉 } 4 \text { 週想定強度 } 40,50,60 \mathrm{~N} / \mathrm{mm}^{2} \\
\text { 粗骨材最大寸法 } 20 \mathrm{~mm} 、 \text { Sl } 21 \mathrm{~cm} 、 \text { Air } 4.5 \%\end{array}$ \\
\end{tabular} \\
\hline & \begin{tabular}{l|l} 
モルタル & 材齢4週想定強度 $50 \mathrm{~N} / \mathrm{mm}^{2}$ \\
セメント $550 \mathrm{Kg} / \mathrm{m}^{3}, \mathrm{C}: \mathrm{S}=1: 3$
\end{tabular} \\
\hline
\end{tabular}

表 2 使用材料

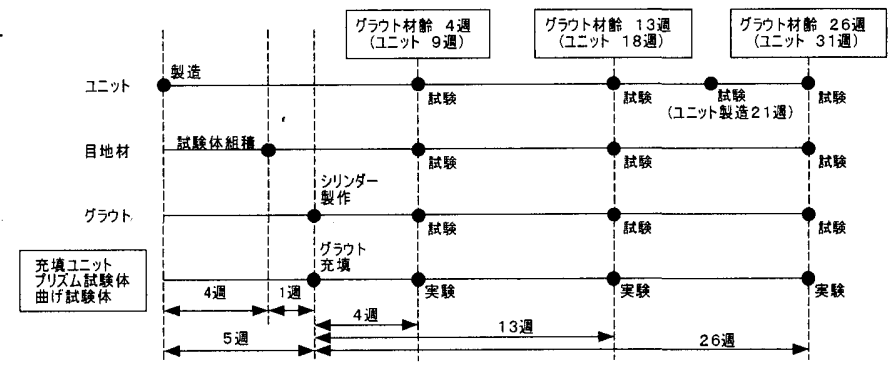

図 3 ユニット製造、試験体製作および実験の工程

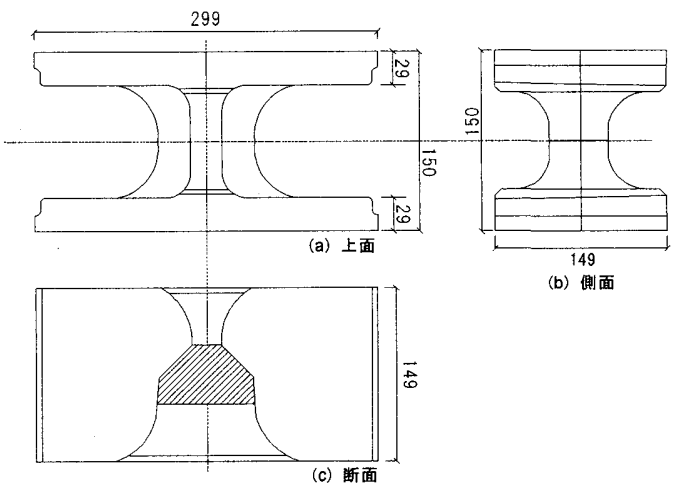

図 4 ユニットの形状

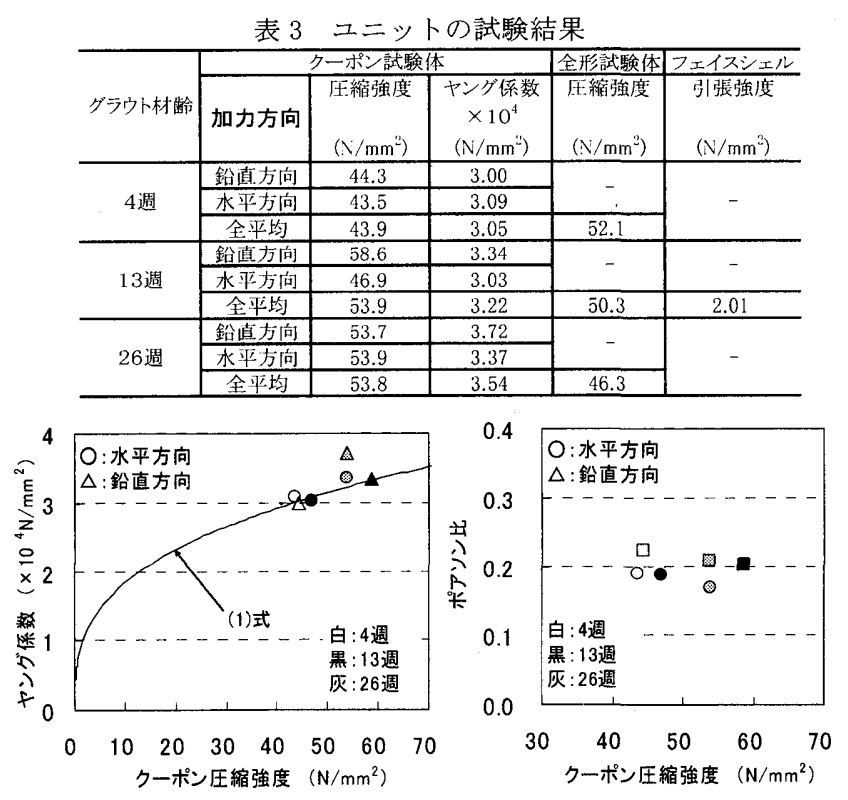

図 5 クーポンのヤング係数図6 クーポンのポアソン比

さらに、ユニット製造後 21 週に（グラウト充填後 16 週）に、ユ ニットの圧縮強度のばらつきを調べるクーポン試験を行った。6 個 のユニットのフェイスシェルの中央部と端部において、クーポン試 験体をそれぞれ 2 体ずつ切り出し、計 24 体の試験体を用いて、端部 と中央部別、鉛直方向と水平方向別の強度を調べた。図 7 に圧縮強 


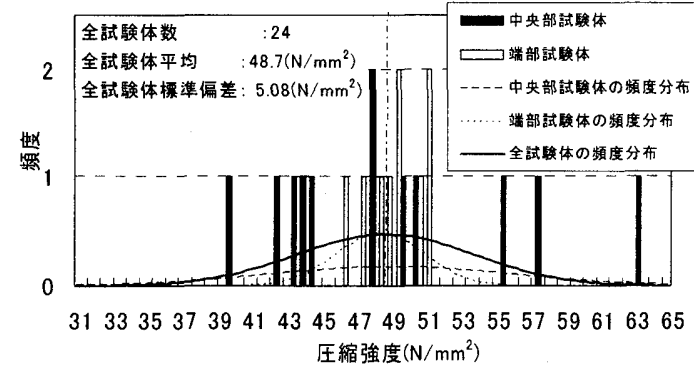

(a) 部位別

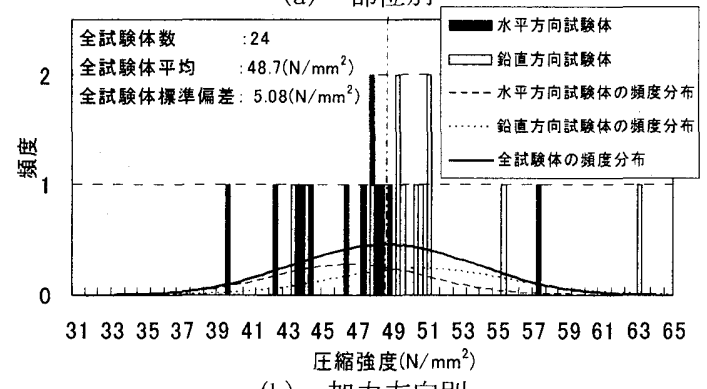

(b) 加力方向別

図 7 クーポン試験体の圧縮強度の分布

度の分布を示す。端部之中央部の圧縮強度の平均值にはほとんど差 異がない。鉛直方向と水平方向では鉛直方向の強度が $8 \%$ 程高くな った。全試験体の圧縮強度の平均は $48.7 \mathrm{~N} / \mathrm{mm}^{2}$ 、標準偏差は $5.04 \mathrm{~N} / \mathrm{mm}^{2}$ であった。

\section{2 グラウト材}

プリズム試験体の加力時に行ったグラウトのシリンダー $(100 \phi \times$ $200 \mathrm{~mm}$ ）の試験結果を表 4 に、圧縮強度とヤング係数、ポアソン比の 関係を図 8 および図 9 に示す。これらは試験体 3 体の平均值である。 また、グラウトの応力一ひずみ関係を、他の材料とともに図 10 に示 す。グラウトの強度は、 4 週から 13 週で $2 \sim 7 \% 、 13$ 週から 26 週で 8〜11\%増加した。グラウトのヤング係数はユニット同様、(1)式と 良好に対応している。ただし、モルタルのヤング係数はコンクリー トに比べ若干低い。ポアソン比は 0.2 近傍に分布している。

なお、グラウトに関しては、前述の充填ユニットと同様に製作し たコア切り出し用充填ユニットからコア供試体 $(83 \phi \times 150 \mathrm{~mm})$ を採 取し、4 週では全グラウト材料、13 週と 26 週では $F_{g} 50$ のコンクリ 一トについて 3 体ずっ圧縮試験を行っている。表 4 に示すシリンダ 一の圧縮強度とコア供試体の圧縮強度（直径と高さによる補正後） を比較すると、コア供試体が若干低い傾向を示した。これはコア切 り出し時に微細な亀裂が発生したことの影響とも考えられる。

\section{3 目地材料}

特殊既調合セメントモルタルのシリンダー $(50 \phi \times 100 \mathrm{~mm})$ の試験 結果を表 5 に示す。このモルタルは早期の接着性の向上を主たる目 的にポリマーディスパージョンを混入するなどして開発したため、 圧縮強度、ヤング係数がニニットやグラウトに比心゙低い值となった。 予備接着剤は、硬化するとほぼゴム状となり弾性的な挙動を示し、 ヤング係数は著しく小さい。

図11に示すように、ユニットのフェイスシェルから切り出して形 状を加工した 2 枚を特殊既調合セメントモルタルおよび打込み目地 $\mathrm{RM}$ 造用予備接着剂を用いて接合し、接着強度試験を行った。なお、 目地厚さが $1 \mathrm{~mm}$ と薄いため、目地を中心にして検長 $30 \mathrm{~mm}$ のひずみゲ
表 4 グラウト材の試験結果

\begin{tabular}{|c|c|c|c|c|c|}
\hline & \multicolumn{2}{|c|}{ シリンダー試験体 } & \multirow{4}{*}{\begin{tabular}{|c|} 
コア供試体 \\
圧縮強度 \\
(補正後) \\
$\left(\mathrm{N} / \mathrm{mm}^{2}\right)$ \\
\end{tabular}} \\
\hline & & & \multirow{3}{*}{$\begin{array}{l}\text { 圧縮強度 } \\
\left(\mathrm{N} / \mathrm{mm}^{2}\right)\end{array}$} & \multirow{3}{*}{$\begin{array}{c}\text { ヤング係数 } \\
\times 10^{4} \\
\left(\mathrm{~N} / \mathrm{mm}^{2}\right) \\
\end{array}$} & \\
\hline 材齢 & 種類 & $F_{g}$ & & & \\
\hline & & $\left(\mathrm{N} / \mathrm{mm}^{2}\right)$ & & & \\
\hline \multirow{4}{*}{ 4週 } & \multirow{3}{*}{ コンクリート } & 40 & 40.1 & 3.16 & 41.0 \\
\hline & & 50 & 49.6 & 3.29 & 46.5 \\
\hline & & 60 & 58.8 & 3.11 & 50.9 \\
\hline & モルタル & 50 & 49.9 & 3.00 & 49.5 \\
\hline \multirow{4}{*}{ 13週 } & \multirow{3}{*}{ コンクリート } & 40 & 43.0 & 3.44 & - \\
\hline & & 50 & 52.5 & 3.46 & 50.0 \\
\hline & & 60 & 59.9 & 3.66 & - \\
\hline & モルタル & 50 & 51.7 & 2.81 & 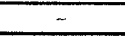 \\
\hline \multirow{4}{*}{ 26週 } & \multirow{3}{*}{ コンクリート } & 40 & 47.9 & 3.29 & - \\
\hline & & 50 & 56.8 & 3.33 & 54.2 \\
\hline & & 60 & 65.9 & 3.69 & - \\
\hline & モルタル & 50 & 57.5 & 2.89 & $=$ \\
\hline
\end{tabular}

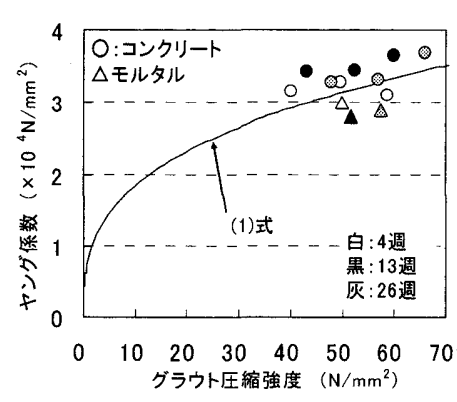

図 8 グラウトのヤング係数

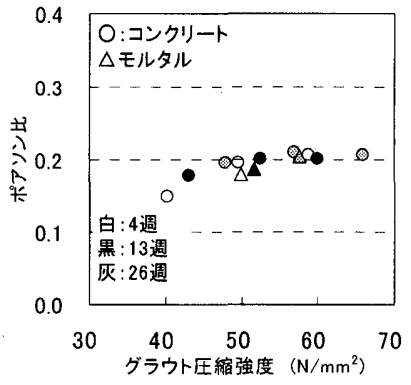

図 9 グラウトのポアソン比

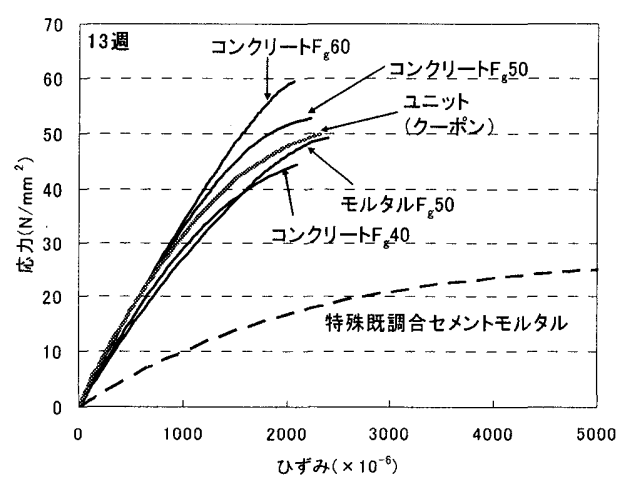

図 10 使用材料の応力一ひずみ関係

表 5 目地材料の試験結果

\begin{tabular}{|c|c|c|c|c|c|}
\hline \multirow{3}{*}{$\begin{array}{c}\text { グラウト } \\
\text { 材歯令 }\end{array}$} & \multirow{2}{*}{\multicolumn{3}{|c|}{ 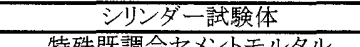 }} & \multicolumn{2}{|c|}{ 接着強度試験 } \\
\hline & & & & \multirow[b]{2}{*}{$\begin{array}{c}\text { 特殊既調合 } \\
\text { セメントモルタル } \\
\left(\mathrm{N} / \mathrm{mm}^{2}\right)\end{array}$} & \multirow{2}{*}{$\begin{array}{c}\text { 打込み目地 } \\
\text { RM造用 } \\
\text { 予備接着蕆! } \\
\left(\mathrm{N} / \mathrm{mm}^{2}\right)\end{array}$} \\
\hline & $\begin{array}{l}\text { 圧縮強度 } \\
\left(\mathrm{N} / \mathrm{mm}^{2}\right)\end{array}$ & $\begin{array}{c}\text { ヤング係数 } \\
\times 10^{4} \\
\left(\mathrm{~N} / \mathrm{mm}^{2}\right)\end{array}$ & $\begin{array}{l}\text { 割裂強度 } \\
\left(\mathrm{N} / \mathrm{mm}^{2}\right)\end{array}$ & & \\
\hline 4週 & 25.7 & 0.94 & 2.97 & 1.85 & 1.30 \\
\hline 13週 & 27.8 & 1.07 & 3.66 & - & - \\
\hline 26週 & 31.7 & 1.09 & 2.91 & - & - \\
\hline
\end{tabular}

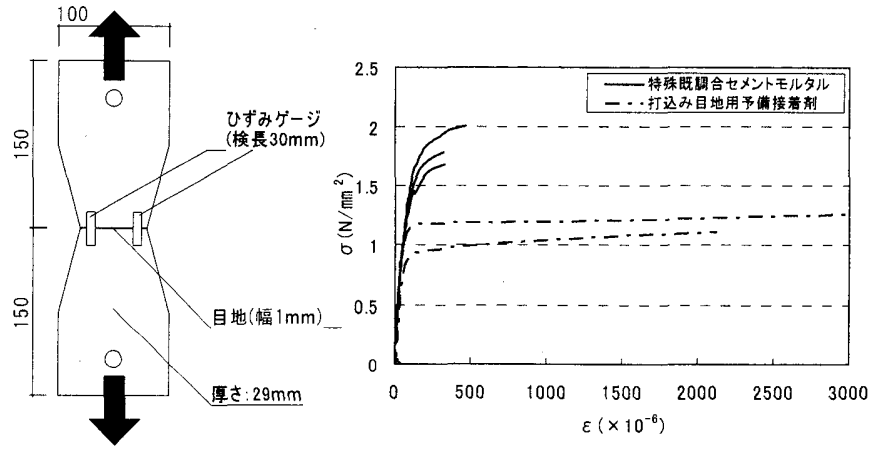

四 11 接着強度試験体の形状 

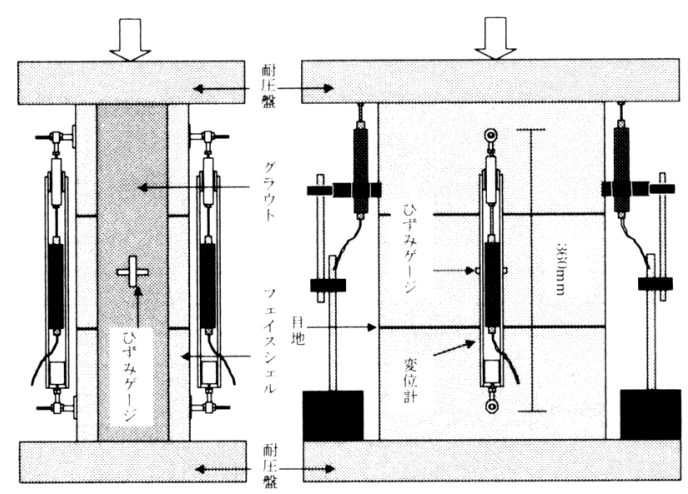

図 13 プリズム試験体の圧縮実験方法

一ジ（前面と背面に 2 枚ずつ）を添付した。試験より得られた接着 強度の平均值を表 5 に示す。特殊既調合セメントモルタルの接着強 度は $1.85 \mathrm{~N} / \mathrm{mm}^{2}$ で、フェイスシェルの引張強度 $2.01 \mathrm{~N} / \mathrm{mm}^{2}$ に近い強度 が得られた。打込み目地 $\mathrm{RM}$ 造用予備接着剂の接着強度は 1.30 $\mathrm{N} / \mathrm{mm}^{2}$ であった。図 12 に目地部の忘力一ひずみ（ひずみゲージ 4 枚 の平均値）関倸を示す。打込み目地 RM造用予備接着剤の場合には 破断時の伸びが大きい。

\section{4.プリズム試験体の圧䊉実験}

\section{1 実験方法および計測方法}

実験は $3000 \mathrm{kN}$ 圧縮試験機を用いて行った。試験体の上下面は硬質石 衰でキャッピングした。図 13 に示すように試験体の 4 つの側面の中 央部にひずみゲージ（検長 $30 \mathrm{~mm}$ ）を貼り付忛表面の縌ひずみと横ひ ずみを測定するとともに、変位計（検長 $360 \mathrm{~mm}$ ) をフェイスシェル の 2 側面に取り付け、目地の変形を含む試験体の变形を測定した。 また、前述の充填ユニットについても、プリズム試験体と同様に $3000 \mathrm{kN}$ 圧縮試験機を用いて圧縮実験を行った。

\section{2 プリズム試験体の応力一ひずみ関係および破壊性状}

図 14 に、実験より得られた試験体の応カーひずみの関係の一例を 示す。応力は計測した荷重をモデュール寸法による断面積（150× $300 \mathrm{~mm}^{2}$ ) で除した值である（以下、ヤング係数、圧縮強度の算定も 同様)。各試験体とも、圧縮強度の $1 / 2$ 程度までは、变位計による縦 ひずみとグラウト部およびフェイスシェル部の縦ひずみの值は同様 に進行している。その後つエイスシェルの横ひずみが急激に拡大す

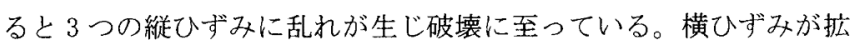
大した時点で、グラウト部分にフェイスシェルに沿った繸ひび割れ が発生し、ユニットとグラウト部の肌別れが生じたと考えられる。

写真 1 に目地材として打込み目地 RM造用予備接着剂を用いた試 験体、写真 2 に特殊既調合セメントモルタルを用いた試験体の最終 破壊状況を示す。写真 1 に示すように、打込み目地用予備接着剤を 用いた試験体では、目地に沿ってフェイスシェルの損傷が生じてい る。一方、特殊既調合セメントモルタルを用いた試験体では目地部 分に集中した損傷は認められず、接合したフェイスシェルは一体と なって挙動したものと考えられる。なお、グラウトの違いによる破 壊性状の差異は明確ではなかった。

\section{5. プリズム試験体のヤング係数およびポアソン比}

プリズム試験体の $1 / 3$ 強度時におうけるヤング係数およびポアソン
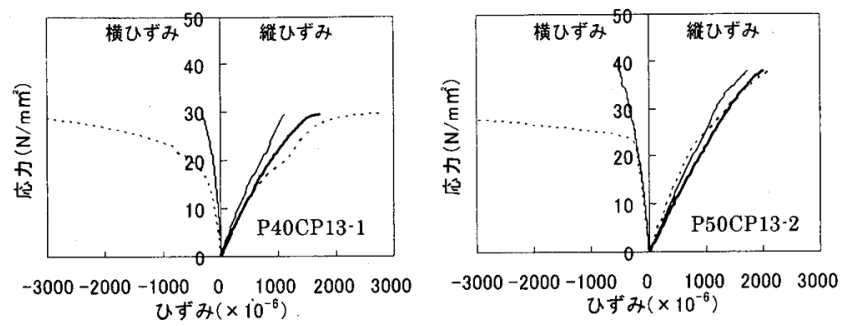

(a) コンクリートF

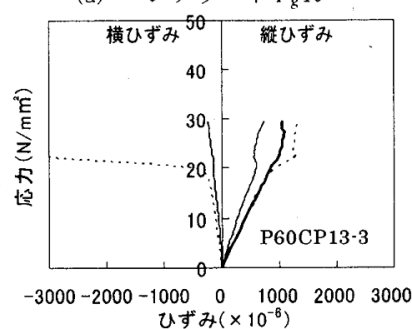

(b) コンクリート F50

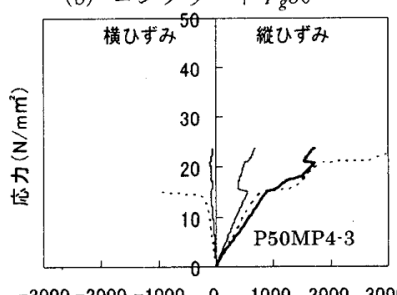

$-3000-2000-1000 \quad 0 \quad 100020003000$ ひずみ $\left(\times 10^{-6}\right)$

(c) コンクリート $F_{g} 60$

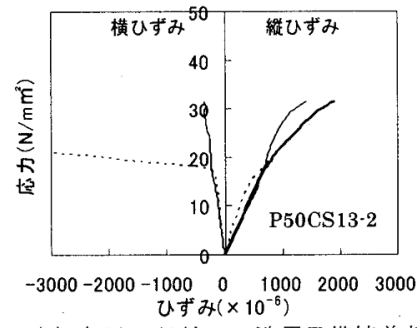

(d) モルタル $F_{g} 50$

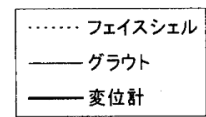

（e）打込み目地 RM造用予備接着剂

図 14 プリズム試験体の応力一ひずみ関係

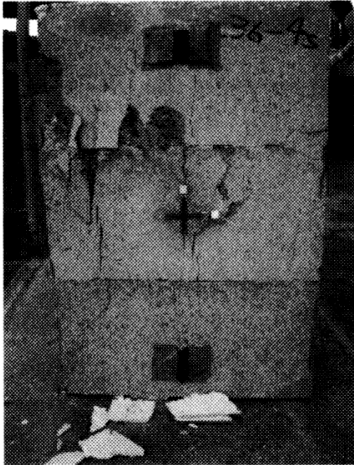

写真 1 最終破壊状況 試験体 P50CS13-1
（打込多目地 R M 造用予備接着剂）（特殊既調合セメントモルタル）

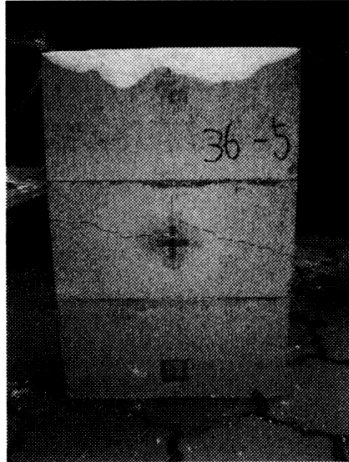

写真 2 最終破壊状況 試験体 P50CP13-2
表 6 プリズム試験体および充填ユニットの実験結果

\begin{tabular}{|c|c|c|c|c|c|c|}
\hline \multirow[b]{3}{*}{ 試験体 } & \multirow[b]{3}{*}{ 材齢 } & \multicolumn{4}{|c|}{ プリズム試験体 } & \multirow{3}{*}{$\begin{array}{l}\text { 充填ユニット } \\
\text { 縮強度 } \\
\left(\mathrm{N} / \mathrm{mm}^{2}\right)\end{array}$} \\
\hline & & \multirow{2}{*}{$\begin{array}{c}\text { ヤング倸数 } \\
\times 10^{4} \\
\left(\mathrm{~N} / \mathrm{mm}^{2}\right)\end{array}$} & \multicolumn{2}{|c|}{ ポアソン比 } & \multirow{2}{*}{$\begin{array}{l}\text { 生縮強度 } \\
\left(\mathrm{N} / \mathrm{mm}^{3}\right)\end{array}$} & \\
\hline & & & グラウト材 & フェイスシェル & & \\
\hline P40CP4 & \multirow{5}{*}{ 4週 } & 2.77 & 0.23 & 0.20 & 28.4 & 34.4 \\
\hline P50CP4 & & 2.97 & 0.26 & 0.21 & 32.6 & 41.9 \\
\hline P60CP4 & & 3.07 & 0.23 & 0.22 & 32.8 & 46.3 \\
\hline P50CS4 & & 2.87 & 0.18 & 0.31 & 29.3 & -- \\
\hline P50MP4 & & 2.41 & 0.19 & 0.17 & 26.1 & 37.8 \\
\hline P40CP13 & \multirow{5}{*}{ 13週 } & 2.47 & 0.28 & 0.15 & 29.4 & 39.5 \\
\hline $\mathrm{P} 50 \mathrm{CP} 13$ & & 2.92 & 0.25 & 0.21 & 35.9 & 45.3 \\
\hline $\mathrm{P} 60 \mathrm{CP} 13$ & & 2.59 & 0.20 & 0.14 & 33.4 & 47.6 \\
\hline P50CS13 & & 2.55 & 0.21 & 0.27 & 29.8 & -- \\
\hline P50MP13 & & 2.40 & 0.16 & 0.17 & 30.7 & 42.5 \\
\hline P40CP26 & \multirow{5}{*}{26 週 } & 2.58 & 0.13 & 0.17 & 30.4 & 38.0 \\
\hline Р50CP26 & & 3.06 & 0.17 & 0.26 & 32.3 & 43.3 \\
\hline $\mathrm{P} 60 \mathrm{CP} 26$ & & 2.78 & 0.17 & 0.19 & 34.0 & 47.0 \\
\hline P50CS26 & & 2.52 & 0.27 & 0.14 & 30.9 & - \\
\hline P50MP26 & & 2.42 & 0.16 & 0.16 & 30.4 & 41.0 \\
\hline
\end{tabular}




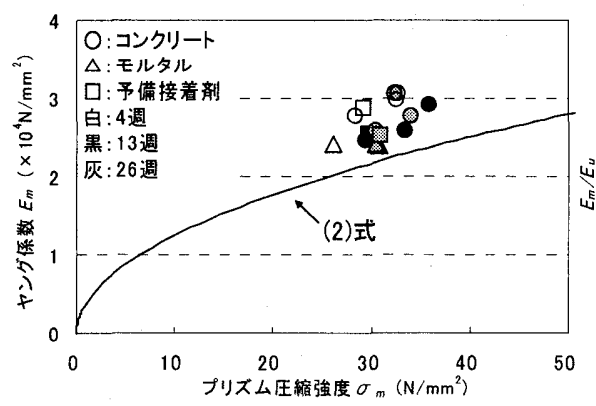

図 15 プリズム試験体のヤング係数 と(2) 式との対忘

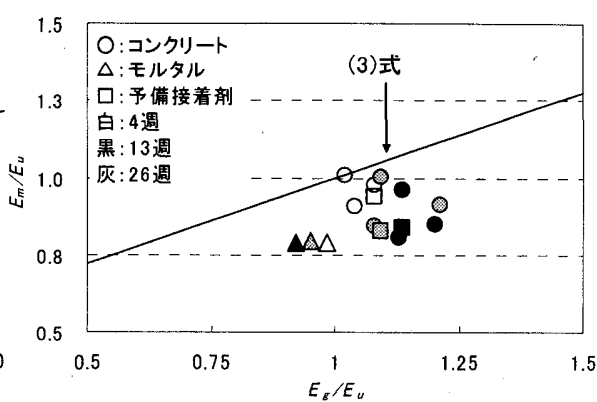

図 16 プリズム試験体のヤング係数 と(3) 式との対応

比を、プリズム試験体および充填ユニットの圧縮強度とともに表 6 に示す。なお、充填ユニットの圧縮強度は、同じグラウトを用いた プリズム試験体と対応させて示してある。ヤング係数は変位計によ る繸ひずみにより求めた。また、ポアソン比は、グラウト部および フェイスシェル部の横ひずみの変位計による縦ひずみに対する比と して求めた。表中の値はす心゙て試験体 3 体の平均值である。グラウ トにコンクリートを用いた試験体を比較すると、コンクリートの強 度が高いものほどヤング係数が大きい（P40CP、P50CP、P60CP の比 較)。グラウトにモルタルを用いた試験体のヤング係数は、コンクリ 一トを用いた試験体のものより小さい（P50MP と P50CP の比較）。ま た、目地材として打込み目地 RM造用予備接着剂を用いたものは、 特殊既調合セメントモルタルを用いたものより若干小さい（P50CS と P $50 \mathrm{CP}$ の比較)。これらは使用材料のヤング係数を反映した結果と 考えられる。

各プリズム試験体のヤング係数と既往の算定式である(2) 式 ${ }^{4)} お$ よび(3)式 ${ }^{4)}$ との対応を図 15 および図 16 に示す。

$$
\begin{aligned}
& E_{m}=1.68 \times 10^{4} \times \sqrt{\frac{\sigma_{m}}{18}} \\
& E_{m}=\left(1-\beta^{\prime}\right) \cdot E_{u}+\beta^{\prime} \cdot E_{g}
\end{aligned}
$$

ここで、

$E_{m}:$ プリズム試験体のヤング係数 $\left(\mathrm{N} / \mathrm{mm}^{2}\right)$

$\sigma_{m}:$ プリズム試験体の压縮強度 $\left(\mathrm{N} / \mathrm{mm}^{2}\right)$

$E_{u}:$ ニニットのヤング係数（クーポンの全平均值とした） $\left(\mathrm{N} / \mathrm{mm}^{2}\right)$ $E_{g}:$ グラウトのヤング倸数（シリンダーの值とした） $\left(\mathrm{N} / \mathrm{mm}^{2}\right)$ $\beta^{\prime}$ : 容積空洞率

(2) 式は本実験のプリズム試験体のヤング係数を若干小さく評価す

る。また、（3)式は実験值に対し高めの評価となっている。

図 17 に各プリズム試験体のポアソン比と圧縮強度との関係を示 す。圧縮強度にかかわりなく、フェイスシェル部もグラウト部もポ アソン比は概㸚 $0.15 \sim 0.3$ の範囲に分布している。

\section{6.プリスム試験体の圧縮強度}

表 6 に示したように、プリズム試験体の圧縮強度は、4 週で 26.1 〜32. $8 \mathrm{~N} / \mathrm{mm}^{2} 、 13$ 週で $29.4 \sim 35.9 \mathrm{~N} / \mathrm{mm}^{2} 、 26$ 週で $30.4 \sim 34.0 \mathrm{~N} / \mathrm{mm}^{2}$ で ある。特殊既調合セメントモルタルを目地材に用い、コンクリート を充填した場合は、 4 週で $28.4 \sim 32.8 \mathrm{~N} / \mathrm{mm}^{2}$ の圧縮強度が得られてい る。また、充填ユニットの圧縮強度は、 4 週で $34.4 \sim 46.3 \mathrm{~N} / \mathrm{mm}^{2} 、 13$ 週で39.5〜 47. $6 \mathrm{~N} / \mathrm{mm}^{2} 、 26$ 週で 38. 0 47. $0 \mathrm{~N} / \mathrm{mm}^{2}$ である。

図 18 にプリズム試験体抢よび充填ユニットの材齢による圧縮強 度の変化を示す。プリズム試験体の圧縮強度は、4 週から 13 週で 2

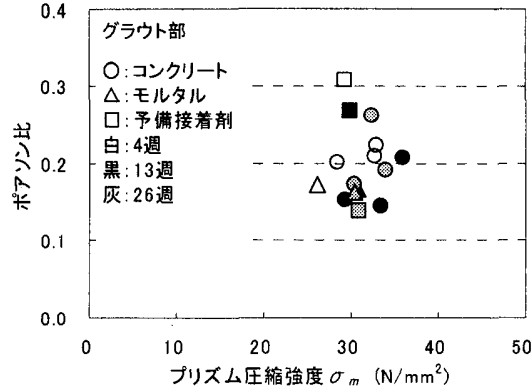

(a) グラウト部

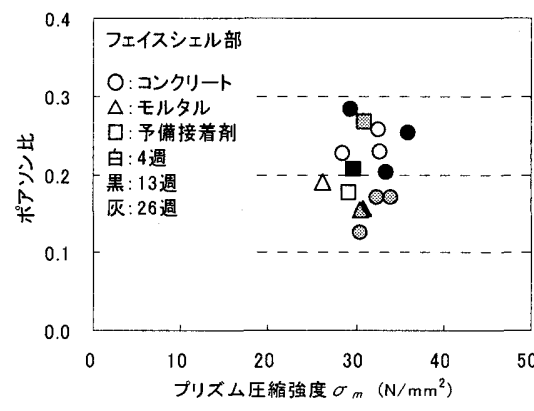

(b) フェイスシェル部

図 17 プリズム試験体のポアソン比

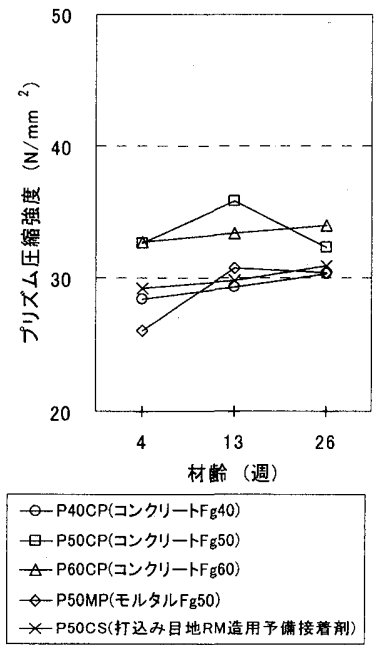

(a) プリズム試験体

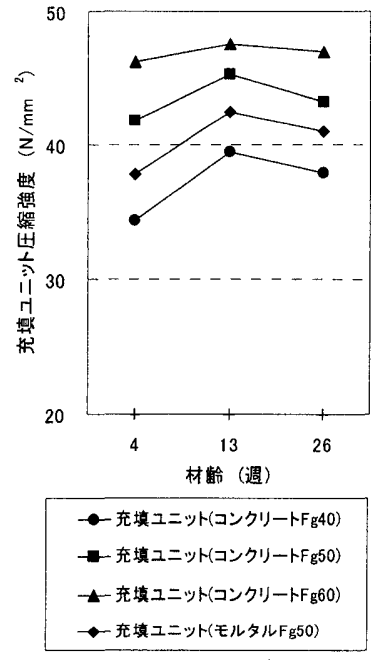

(b) 充填ユニット
図 18 材齢による試験体の圧縮強度の変化

〜 18\%増加、13 週から 26 週でP50CP と P50MP は減少し、他は 2 4\% 増加した。また、充填ユニットの圧縮強度は、4週から 13 週で 3 $15 \%$ 增加したが、13 週から 26 週で1〜5\%減少した。

図 19 に、プリズム試験体および充填ユニットの圧縮強度とグラウ トの圧縮強度との関係を示す。白印がプリズム試験体、黒印が充填 ユニットを表す。図中の直線は、構造設計指針 ${ }^{4}$ ) $\mathrm{R} \mathrm{M}$ 組積体の設 計基準強度算定式として用いられている文献 ${ }^{5)}$ のプリズム圧縮強度 推定式 [(4) 式]の組積係数 $e_{s}$ の大きさを表している。

$\sigma_{m}=e_{s}\left\{\left(1-\beta^{\prime}\right) \cdot \sigma_{n}+\beta^{\prime} \cdot \sigma_{g}\right\}$

ここで、 $e_{s}:$ 組積係数

$$
\begin{gathered}
\sigma_{g}: \text { グラウトの圧縮強度 }\left(\mathrm{N} / \mathrm{mm}^{2}\right) \\
\sigma_{u}: \text { ユニットの圧縮強度 }\left(\mathrm{N} / \mathrm{mm}^{2}\right)
\end{gathered}
$$

$e_{s}$ を表す直線は、縦軸を $\sigma_{m}$ 、横軸を $\sigma_{\mathrm{g}}$ として、 $\sigma_{u}$ は 4 週および 


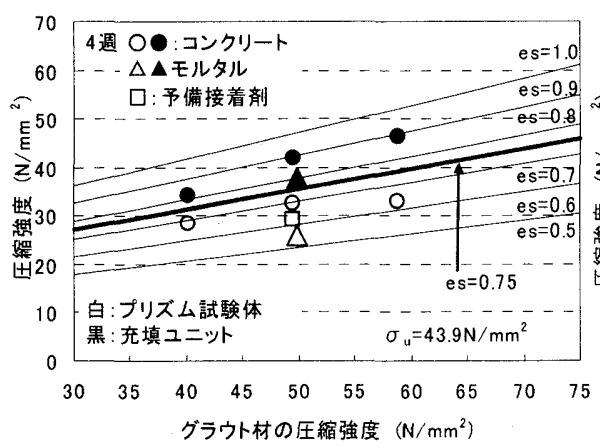

(a) 4 週

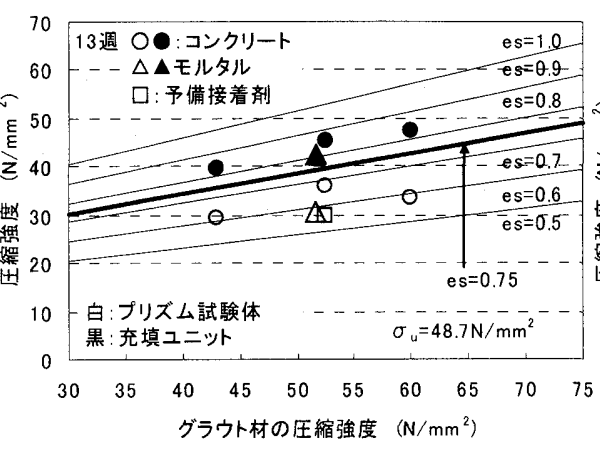

(b) 13 週

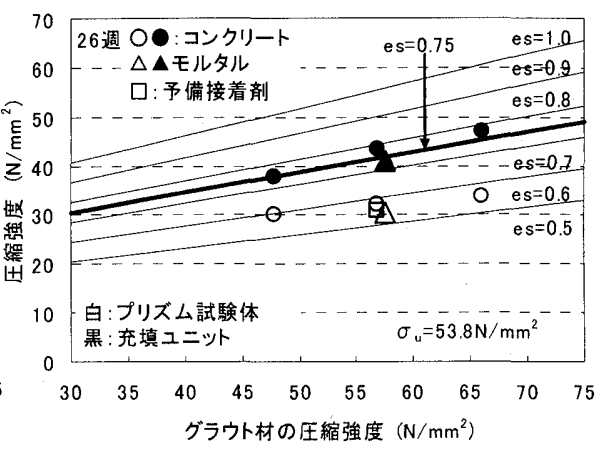

(c) 26 週

図 19 プリズム試験体および充填ユニットの圧縮強度と組積係数

26 週ではクーポンの全平均の圧縮強度を用いて算定した。13 週では、 クーポンの強度のばらつきが大きいことから、材路が近い 16 週のク ーポン試験（図 7 参照）の平均值 $48.7 \mathrm{~N} / \mathrm{mm}^{2}$ を $\sigma_{u}$ とした。

プリズム試験体の圧縮強度は、目地に特殊既調合セメントモルタ ルを用い、グラウトがコンクリートの試験体では、 $F_{g} 40$ に比べて $F_{g} 50$ が大きい。 $F_{g} 60$ は $F_{g} 50$ と比べて、26 週では大きいが 4 週と 13 週では逆に小さくなっており、強度のばらつきが見られた。また、 グラウトとしてモルタルを用いた試験体および目地に予備接着剤を 用いた試験体の圧縮強度は、グラウトとして同じ強度のコンクリー 卜、目地材として特殊既調合セメントモルタルを用いた場合より小 さくなった。

充填ユニットの压縮強度は、グラウトがモルタルの場合、同じ強 度のコンクリートのものより小さい。また、コンクリートの強度が 高いほど圧縮強度も高くなっている。なお、特殊既調合セメントモ ルタルを用いたプリズム試験体の圧縮強度は、各材齢とも充填二ニ ットの圧縮強度の概ね 70 ～ $80 \%$ であり、ユニットとグラウトの適切 な強度の組合せを選定する上で、充填ユニットの圧縮実験は簡便で 有効な方法と考えられる。ただし、プリズム試験体と充填ユニット の強度の差異には、目地の存在とともに試験体の高さと幅の比も影 響していると考えられる。これについては、今後検討していく必要 がある。

試験体の $e_{s}$ の值は、充填ユニットでは概ね $0.8 \sim 0.9$ の範囲にあ る。また、プリズム試験体では概ね $0.55 \sim 0.7$ の範网にある。プリ ズム試験体の組積係数は、標準的な值である 0.75 に比べ若干小さな 值となった。これは目地材の圧縮強度やヤング係数がユニットやグ ラウトに比べ小さかったことによる影響とも考えられるが、これに 関しては、今後、特殊既調合セメントモルタルの高強度化などを図 る必要があるう。なお、図 19 に示寸ように、材齢が進むにつれ、特 に材齢 26 週で、充填ユニット、プリズム試験体とも組積係数が小さ くなっている。これは、ユニットおよびグラウト材の材龄に伴う強 度の増加に比べ、充填ニニットおよびプリズム試験体は強度の増加 が認められなかったことによる。

\section{7. まとめ}

本論では、壁厚を $150 \mathrm{~mm}$ とする鉄筋コンクリート組積造の構工 法の提案を行うとともに、新しく開発した $40 \mathrm{~N} / \mathrm{mm}^{2}$ クラスのコンク リートニニットの材料特性およびそのニニット用いて製作したプリ ズム試験体の圧縮性状を報告した。本論で明らかにした主要な知見
を以下に記す。

1) 本ユニットの製造後 9 週 (グラウト充填後 4 週) の圧縮強度は 43.9 $\mathrm{N} / \mathrm{mm}^{2}$ であった。ニニットには方向別に強度のばらつきがあるが、 その差異は小さい。

2)本ユニットのフェイスシェルを極薄目地構法により特殊既調合セ メントモルタルを用いて接合した場合、接合後 5 週（グラウト充 填後 4 週）の接着強度は $1.85 \mathrm{~N} / \mathrm{mm}^{2}$ となった。この值はニニット のフェイスシェルの引張強度に近い值である。

3) 本ユニットを極薄目地構法により特殊既調合セメントモルタルを 用いて組積し、40〜60N/ $\mathrm{mm}^{2}$ のコンクリートを充填した場合、充填 後 4 週で $28.4 \sim 32.8 \mathrm{~N} / \mathrm{mm}^{2}$ のプリズム压縮強度が得られた。グラ ウトとしてモルタルを用いた場合、目地材に打込み目地 RM造用 予備接着剤を用いた場合にはプリズム圧縮強度が低下する。

4) 本実験のプリズム試験体の組積係数は、概ね $0.55 \sim 0.7$ の範囲に あった。

なお、.文献 ${ }^{1)}$ では設計基準強度を $27 \mathrm{~N} / \mathrm{mm}^{2}$ とする壁厚 $150 \mathrm{~mm}$ の 3 階 建てRM造建築物の試設計例を示している。本実験の結果より、圧 縮強度の観点からは、本ニニットを用いて 3 階建て R M 造建築物が 実現可能であると考えている。

\section{謝辞}

本実験の実施に際し、太陽セメント工業（株）泉北工場、泉北第 2 工場の皆様には大変お世話になりました。記して謝意を表します。

\section{参考文献}

〔1〕山本大介、稲井栄一：小型ユニットを用いた R M 造建築物の試設計、日 本建築学会大会学術講演梗概集、構造IV、p. 797-798、2006 年 9 月

[2] 山下亮、稻井栄一、高橋和雄、山本大介、花岡鉄兵、石井克侑：小型二 ニットを用いた R M 組積体の軸圧縮特性、日本建築学会中国支部研究報 告集、第 30 巻、pp. 149-152，2007 年 3 月

[3]花岡鉄兵、稲井栄一、高橋和雄、山本大介、山下亮、石井克侑：小型工 ニットを用いたR M 組積体の面外曲げ特性、日本建築学会中国支部研究 報告集、第 30 巻、pp. 153-156, 2007 年 3 月

[4]（社）建築研究振興協会：鉄筋コンクリート組積造（RM造）建築物の) 構造設計指針・同解説、2004 年 12 月

（5）馬場明生、渡辺光良、千歩修、木島五郎：組積造に関する日米共同大型

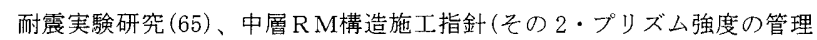
法)、日本建築学会大会学術講演梗概集、材料施工、pp. 717-718、1988 年 10 月

[2007年 4 月20日原稿受理２007年 7 月26日採用決定］ 